\title{
Differentiation of Regioisomeric Aromatic Ketocarboxylic Acids by Positive Mode Atmospheric Pressure Chemical Ionization Collision-Activated Dissociation Tandem Mass Spectrometry in a Linear Quadrupole Ion Trap Mass Spectrometer
}

\author{
Lucas M. Amundson, ${ }^{1}$ Benjamin C. Owen, ${ }^{1}$ Vanessa A. Gallardo, ${ }^{1}$ Steven C. Habicht, ${ }^{1,3}$ \\ Mingkun Fu, ${ }^{1,4}$ Ryan C. Shea, ${ }^{2}$ Allen B. Mossman, ${ }^{2}$ Hilkka I. Kenttämaa ${ }^{1}$ \\ ${ }^{1}$ Department of Chemistry, Purdue University, BRWN Building, 560 Oval Dr., West Lafayette, IN 47907, USA \\ ${ }^{2}$ British Petroleum (BP), Naperville, IL 60563, USA \\ ${ }^{3}$ Center for Naval Analysis, 4825 Mark Center Drive, Alexandria, VA 22311, USA \\ ${ }^{4}$ Millennium, 40 Landsdowne Street, Cambridge, MA 02139, USA
}

\begin{abstract}
Positive-mode atmospheric pressure chemical ionization tandem mass spectrometry (APCl$\mathrm{MS}^{n}$ ) was tested for the differentiation of regioisomeric aromatic ketocarboxylic acids. Each analyte forms exclusively an abundant protonated molecule upon ionization via positive-mode APCl in a commercial linear quadrupole ion trap (LQIT) mass spectrometer. Energy-resolved collision-activated dissociation (CAD) experiments carried out on the protonated analytes revealed fragmentation patterns that varied based on the location of the functional groups. Unambiguous differentiation between the regioisomers was achieved in each case by observing different fragmentation patterns, different relative abundances of ion-molecule reaction products, or different relative abundances of fragment ions formed at different collision energies. The mechanisms of some of the reactions were examined by $\mathrm{H} / \mathrm{D}$ exchange reactions and molecular orbital calculations.
\end{abstract}

Key words: Atmospheric pressure chemical ionization, Tandem mass spectrometry, Regioisomers, Aromatic carboxylic acids

\section{Introduction}

$\mathrm{B}$ ioenergy and biomaterials can be produced from renewable plant biomass, an abundant carbon-neutral resource [1-4]. Biofuels derived from such a resource may offer an alternate and renewable approach for current liquid transportation fuels. Lignin, a complex biopolymer containing phenylpropane and methoxy groups, is a major component

Correspondence to: Hilkka Kenttämaa; e-mail: hilkka@purdue.edu present in all lignocellulosic biomass [4-6]. Lignocellulosic biofuel and other valuable chemicals can be produced from non-grain crops, capable of yielding large amounts of biomass [1,7]. However, the complexity of structure and large amounts of oxygens in lignin hinder its use for this purpose $[3,5,6]$. The ability to identify products arising from lignin following digestion or degradation is key to addressing this problem.

Mass spectrometry (MS) has evolved into an essential tool for the identification of unknown substances in 
Table 1. Summary of the main fragment ions observed in positive-mode APCI/MS ${ }^{n}$ for protonated benzoylbenzoic acids

\begin{tabular}{|c|c|c|c|c|}
\hline Analyte (MW) & $\mathrm{MS}(\mathrm{m} / \mathrm{z})$ & $\begin{array}{l}\mathrm{MS}^{2} \mathrm{CAD} \text { fragments and } \\
\text { other products }(\mathrm{m} / \mathrm{z})\end{array}$ & $\begin{array}{l}\mathrm{MS}^{3} \mathrm{CAD} \text { fragments and } \\
\text { other products }(\mathrm{m} / \mathrm{z})\end{array}$ & $\begin{array}{l}\mathrm{MS}^{4} \text { CAD fragments and } \\
\text { other products }(\mathrm{m} / \mathrm{z})\end{array}$ \\
\hline $\begin{array}{l}\text { 2-Benzoylbenzoic acid } \\
\text { (226) }\end{array}$ & {$[\mathrm{M}+\mathrm{H}]^{+}(227)$} & $227-\mathrm{H}_{2} \mathrm{O}(209)[100 \%]$ & $\begin{array}{l}209-\mathrm{CO}(181)[17 \%] \\
209-2 \mathrm{CO}(153)[83 \%]\end{array}$ & $181-\mathrm{CO}(153)[100 \%]$ \\
\hline $\begin{array}{l}\text { 3-Benz } \\
\text { (226) }\end{array}$ & {$[\mathrm{M}+\mathrm{H}]^{+}(227)$} & $\begin{array}{l}227-\mathrm{C}_{6} \mathrm{H}_{6}(149)[90 \%] \\
227-\mathrm{C}_{6} \mathrm{H}_{6}-\mathrm{CO}_{2}(105)[10 \%]\end{array}$ & $\begin{array}{l}149-\mathrm{CO}(121)[62 \%] \\
149-\mathrm{CO}+\mathrm{H}_{2} \mathrm{O}(139)^{\mathrm{a}}[31 \%] \\
149-\mathrm{CH}_{2} \mathrm{CO}(107)[7] \\
105-\mathrm{CO}(77)[64 \%] \\
105-\mathrm{CO}+\mathrm{H}_{2} \mathrm{O}(95)^{\mathrm{a}}[16 \%] \\
105-\mathrm{CO}+\mathrm{H}_{2} \mathrm{O}-\mathrm{CH}_{2} \mathrm{CO}(53) \\
{[20 \%]}\end{array}$ & $\begin{array}{l}121-\mathrm{CO}(93)[28 \%] \\
121-2 \mathrm{CO}(65)[72 \%]\end{array}$ \\
\hline $\begin{array}{l}\text { 4-Benzoylbenzoic acid } \\
\text { (226) }\end{array}$ & {$[\mathrm{M}+\mathrm{H}]^{+}(227)$} & $\begin{array}{l}227-\mathrm{C}_{6} \mathrm{H}_{6}(149)[88 \%] \\
227-\mathrm{C}_{6} \mathrm{H}_{6}-\mathrm{CO}_{2}(105)[12 \%]\end{array}$ & $\begin{array}{l}149-\mathrm{CO}(121)[47 \%] \\
149-\mathrm{CO}+\mathrm{H}_{2} \mathrm{O}(139)^{\mathrm{a}}[51 \%] \\
149-\mathrm{CH}_{2} \mathrm{CO}(107)[2 \%] \\
105-\mathrm{CO}(77)[63 \%] \\
105-\mathrm{CO}+\mathrm{H}_{2} \mathrm{O}(95)^{\mathrm{a}}[17 \%] \\
105-\mathrm{CO}+\mathrm{H}_{2} \mathrm{O}-\mathrm{CH}_{2} \mathrm{CO}(53) \\
{[20 \%]}\end{array}$ & $\begin{array}{l}121-\mathrm{CO}(93)[27 \%] \\
121-2 \mathrm{CO}(65)[73 \%]\end{array}$ \\
\hline
\end{tabular}

${ }^{\mathrm{a}}$ Ion-molecule reaction with adventitious $\mathrm{H}_{2} \mathrm{O}$.

mixtures [8, 9]. With the onset of many new ionization methods, such as electrospray ionization (ESI), atmospheric pressure photoionization (APPI), and atmospheric pressure chemical ionization (APCI), MS has become a valuable tool for mixture analyses, especially when combined with high-performance liquid chromatography (HPLC) $[10,11]$. However, this approach often only allows for the determination of molecular weights and

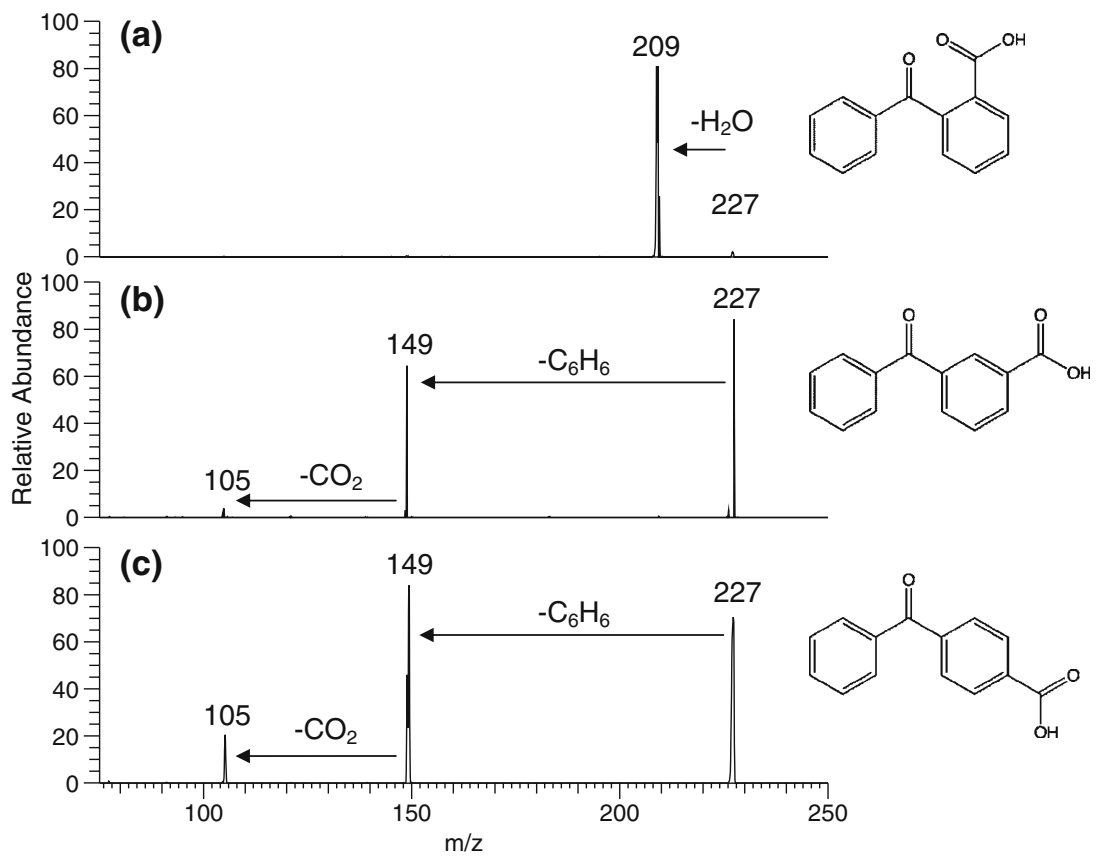

Figure 1. CAD mass spectra of isolated protonated (a) 2-benzoylbenzoic acid, (b) 3-benzoylbenzoic acid, and (c) 4benzoylbenzoic acid (all of $\mathrm{m} / \mathrm{z} 227$ ) 


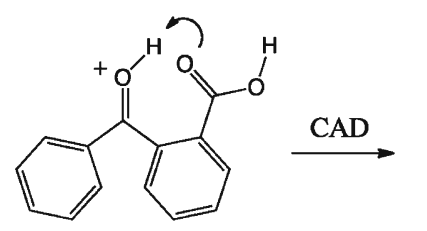

$\mathrm{m} / \mathrm{z} 227$<smiles>CCCCCc1ccccc1C(=O)c1ccccc1</smiles><smiles>CCO[C+]1CCCO[O+]1c1ccccc1C(=O)c1ccccc1</smiles><smiles>O=C([OH2+])c1ccccc1C(=O)c1ccccc1</smiles><smiles>[194Po]</smiles><smiles>O=C([OH2+])c1ccccc1C(=O)O[Na]</smiles>

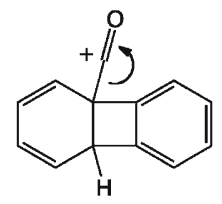

$\mathrm{m} / \mathrm{z} 181$<smiles>CC(C)(C)COCc1ccccc1C(=O)c1ccccc1</smiles>

$\mathrm{m} / \mathrm{z} 209$<smiles>C1=C[C+]2c3ccccc3C2C=C1</smiles>

$\mathrm{m} / \mathrm{z} 153$

Scheme 1. Possible mechanisms for the consecutive losses of water and two CO molecules from protonated 2-bensoylbenzoic acid

elemental compositions (for high resolution mass spectrometers) of unknown analytes. Therefore, tandem mass spectrometry $\left(\mathrm{MS}^{n}\right)$, i.e., isolation of a molecular or pseudo-molecular ion and examination of its reactions, is often employed to obtain structural information. The most common approach utilizes collision-activation dissociation (CAD) to generate structurally characteristic fragmentation patterns. This is sometimes carried out in an energyresolved manner in order to obtain more detailed structural information [9, 12-18].

CAD-based $\mathrm{MS}^{n}$ techniques have been applied to the characterization of unknown substances in many fields, including the pharmaceutical industry [19, 20], and research on chemical warfare agents [21], proteins [22], volatile organic compounds [23], airborne oxidants [24], bacteria, DNA [25, 26], and microextracted water samples [27]. Hydrogen/deuterium (H/D) exchange experiments [28-30] and molecular orbital calculations [31, 32] have facilitated the differentiation of isomeric compounds.

The vast interest in the development of biofuels from lignocellulosic degradation products has created the necessity to structurally characterize unknown aromatic compounds containing several oxygen functionalities in complex mixtures $[2,6,7]$. Unfortunately, many common oxygen-containing compounds, including carboxylic acids, do not produce stable protonated molecules when ionized by the commonly employed positive-mode ESI. Hence, such compounds have been generally analyzed using negative-mode ESI due to their acidic nature [33-35]. Regrettably, the majority of this past work provides no structural information that would allow, for example, the differentiation of isomers. We report here on the application of positive mode APCI, another soft atmospheric ionization method, and $\mathrm{MS}^{n}$, for the differentiation of regioisomeric oxygen-containing aromatic compounds.<smiles>CC(C)C(C(=O)c1cccc(C(=O)O)c1)c1cccc(C(=O)O)c1</smiles>

$\mathrm{m} / \mathrm{z} 227$

$\mathrm{m} / \mathrm{z} 149$

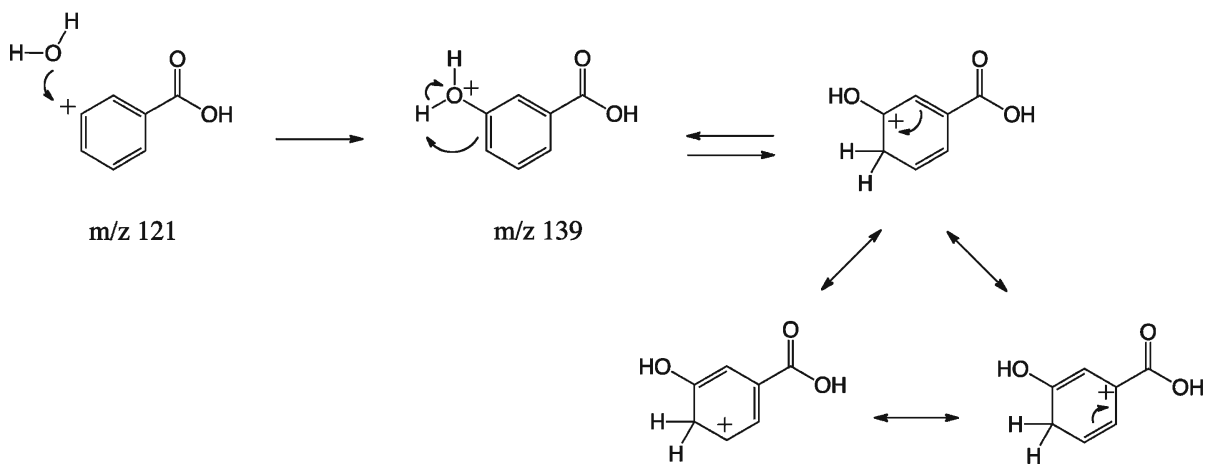

Scheme 2. Possible mechanisms for the consecutive losses of benzene and CO followed by addition of water for protonated 3-bensoylbenzoic acid 


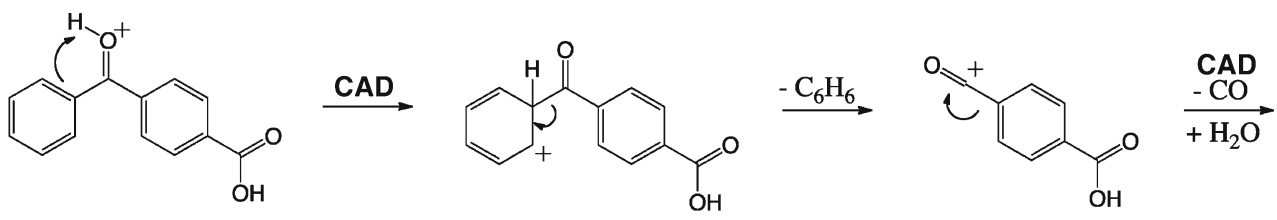

$\mathrm{m} / \mathrm{z} 227$<smiles>O=C(O)c1ccc(CO)cc1</smiles>

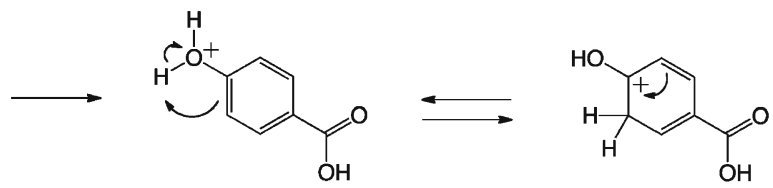

$\mathrm{m} / \mathrm{z} 121$ $\mathrm{m} / \mathrm{z} 139$

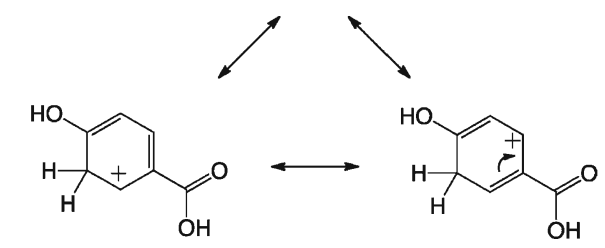

Scheme 3. Possible mechanisms for the consecutive losses of benzene and CO followed by addition of water for protonated 4-bensoylbenzoic acid

\section{Experimental}

\section{Materials}

2-Benzoylbenzoic acid ( $>98 \%$ purity), 3-benzoylbenzoic acid ( $>99 \%$ purity), 4-benzoylbenzoic acid ( $>\%$ purity), 9-fluorenone-1-carboxylic acid ( $>99 \%$ purity), 9-fluorenone-2-carboxylic acid ( $>98 \%$ purity), and 9-fluorenone-4-carboxylic acid

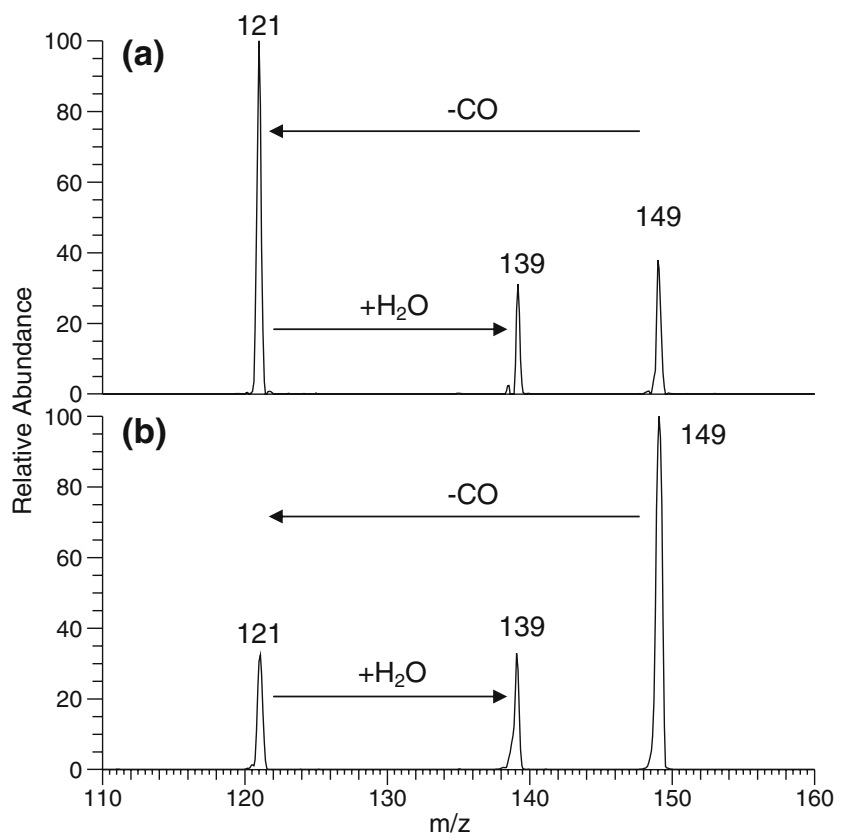

Figure 2. CAD mass spectra of the isolated fragment ion of $\mathrm{m} / \mathrm{z} 149$ formed upon CAD of isolated protonated (a) 3benzoylbenzoic acid and (b) 4-benzoylbenzoic acid. Addition of water to the fragment ion of $\mathrm{m} / \mathrm{z} 121$ occurs during the CAD time period
( $>97 \%$ purity) were obtained from Sigma-Aldrich (St. Louis, MO, USA). HPLC grade $\mathrm{H}_{2} \mathrm{O}$ was purchased from Burdick and Jackson (Muskegon, MI, USA), and HPLC grade $\mathrm{CH}_{3} \mathrm{CN}$ was purchased from Mallinkrodt (St. Louis, MO, USA). Methanol-D $\mathrm{D}_{4}(\mathrm{D}, 99.8 \%)$ was purchased from Cambridge Isotope Laboratories Inc. (Andover, MA, USA). All chemicals were used as received without further purification.

\section{Methods}

Mass spectrometry experiments were performed in a Finnigan LTQ linear quadrupole ion trap (LQIT) mass spectrometer equipped with an atmospheric pressure chemical ionization (APCI) source. Sample solutions were prepared at $30 \mu \mathrm{g} / \mathrm{mL}\left(\sim 10^{-3} \mathrm{M}\right)$ concentrations in $100 \%$ $\mathrm{CH}_{3} \mathrm{CN}, 100 \% \mathrm{CH}_{3} \mathrm{OH}, 50 / 50$ (vol/vol) $\mathrm{H}_{2} \mathrm{O} / \mathrm{CH}_{3} \mathrm{CN}$, or $50 /$ 50 (vol/vol) $\mathrm{H}_{2} \mathrm{O} / \mathrm{CH}_{3} \mathrm{OH}$. The solutions were infused at $10 \mu \mathrm{L} / \mathrm{min}$ using the integrated syringe drive of the LQIT and combined via an HPLC tee with the HPLC eluent, 50/50 (vol/vol) $\mathrm{H}_{2} \mathrm{O} / \mathrm{CH}_{3} \mathrm{CN}$ or $50 / 50$ (vol/vol) $\mathrm{H}_{2} \mathrm{O} / \mathrm{CH}_{3} \mathrm{OH}$, delivered at a rate of $100 \mu \mathrm{L} / \mathrm{min}$ by a Finnigan Surveyor MS Pump Plus. The resulting mixture was introduced into the APCI source. The samples were dissolved in $100 \%$ $\mathrm{CD}_{3} \mathrm{OD}$ in order to conduct hydrogen/deuterium (H/D) exchange experiments. These solutions were directly infused into the APCI source (i.e., they were not introduced into the source with HPLC eluent via the HPLC tee). Typical APCI conditions were used: discharge current, $5.0 \mu \mathrm{A}$; vaporizer temperature, $450{ }^{\circ} \mathrm{C}$; sheath gas $\left(\mathrm{N}_{2}\right)$ flow, 50 (arbitrary units); auxiliary gas $\left(\mathrm{N}_{2}\right)$ flow, 20 (arbitrary units); sweep gas $\left(\mathrm{N}_{2}\right)$ flow, 5 (arbitrary units); and capillary temperature, $250{ }^{\circ} \mathrm{C}$. Voltages for the ion optics were optimized for each analyte by using the tune feature of the LTQ Tune Plus interface. 

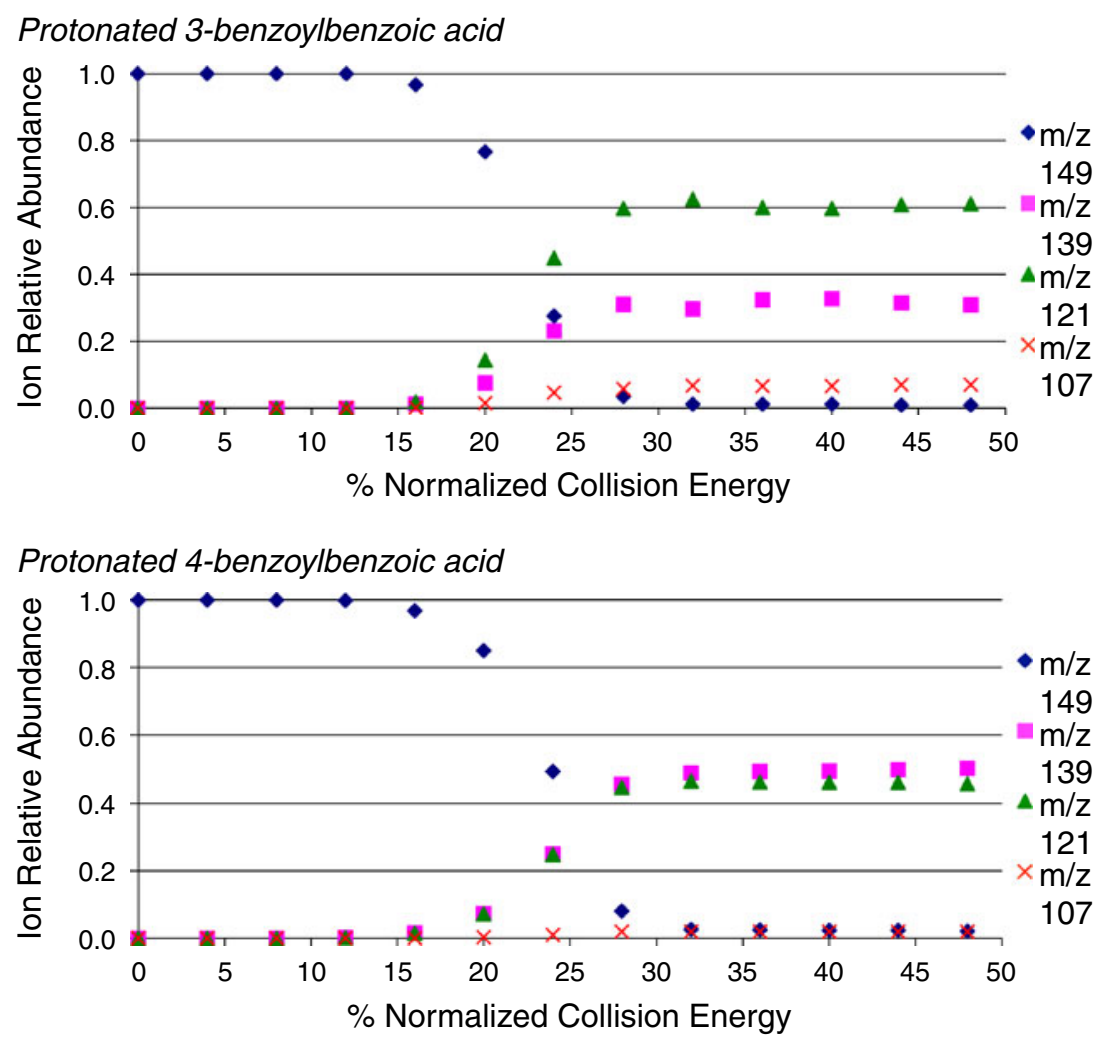

Figure 3. Energy-resolved CAD mass spectra of the fragment ion of $\mathrm{m} / \mathrm{z} 149$ of protonated 3-benzoylbenzoic and 4benzoylbenzoic acids. The product ion of $\mathrm{m} / \mathrm{z} 139$ is an ion-molecule reaction product of the fragment ion of $\mathrm{m} / \mathrm{z} 121$

$\mathrm{MS}^{n}$ experiments were performed using the advanced scan features of the LTQ Tune Plus interface. The protonated analyte was isolated using a $1-3$ Th window and a $\mathrm{q}$ value of 0.25 , then fragmented by applying an appropriate activation voltage (defined by the LTQ Tune Plus interface), generally $10 \%-30 \%$ of the "normalized collision energy" [36]. Xcalibur 2.0 software (Thermo) was used for both data acquisition and processing. All mass spectra shown are an average of at least 20 scans.

\section{Computational Studies}

All molecular orbital calculations were performed with the Gaussian03 E.01 program [37]. Geometry optimizations and vibrational frequency calculations were carried out by using density functional theory at the B3LYP/6-31G(d) level. Vibrational frequencies were calculated in order to verify that the stationary points obtained correspond to minima and not transition states (no imaginary frequencies). Reported energies, at $298 \mathrm{~K}$, include the zero-point vibrational energy (ZPVE) correction. The calculated enthalpies of reaction include the enthalpy correction to the ground state energies. The proton affinities of the analytes were calculated using the isodesmic reaction scheme involving benzophenone as a reference Brønsted base.

\section{Results and Discussion}

Three regioisomeric benzoylbenzoic acids and three regioisomeric 9-fluorenone carboxylic acids were examined via $(+)$ APCI/MS ${ }^{n}$. Each of these analytes formed solely a stable protonated molecule upon APCI. The regioisomers were differentiated based on energy-resolved CAD or ion-molecule reaction data. Some of the proposed reaction sequences were probed by molecular orbital calculations and H/D exchange experiments. A detailed discussion is provided below.

\section{Benzoylbenzoic Acid Isomers}

The CAD spectra measured for three isolated protonated benzoylbenzoic acid regioisomers were found to vary based on the location of the functional groups (Table 1). When the carboxylic acid functionality is close to the keto group (2benzoylbenzoic acid), the ion fragments by exclusive loss of $\mathrm{H}_{2} \mathrm{O}(\mathrm{m} / \mathrm{z} 209)$ (Fig. 1a). This loss is most likely facilitated by the close proximity of the two functionalities (Scheme 1). The same was not observed for the 3- and 4-isomers. Thus, $\mathrm{CAD}\left(\mathrm{MS}^{2}\right)$ allows for the immediate differentiation of the 2-isomer from the 3- and 4-isomers.

The protonated 3-benzoylbenzoic and 4-benzoylbenzoic acids fragment by cleavage of the carbonyl-phenyl bond, resulting in an abundant ion of $\mathrm{m} / \mathrm{z} 149$ via elimination of 


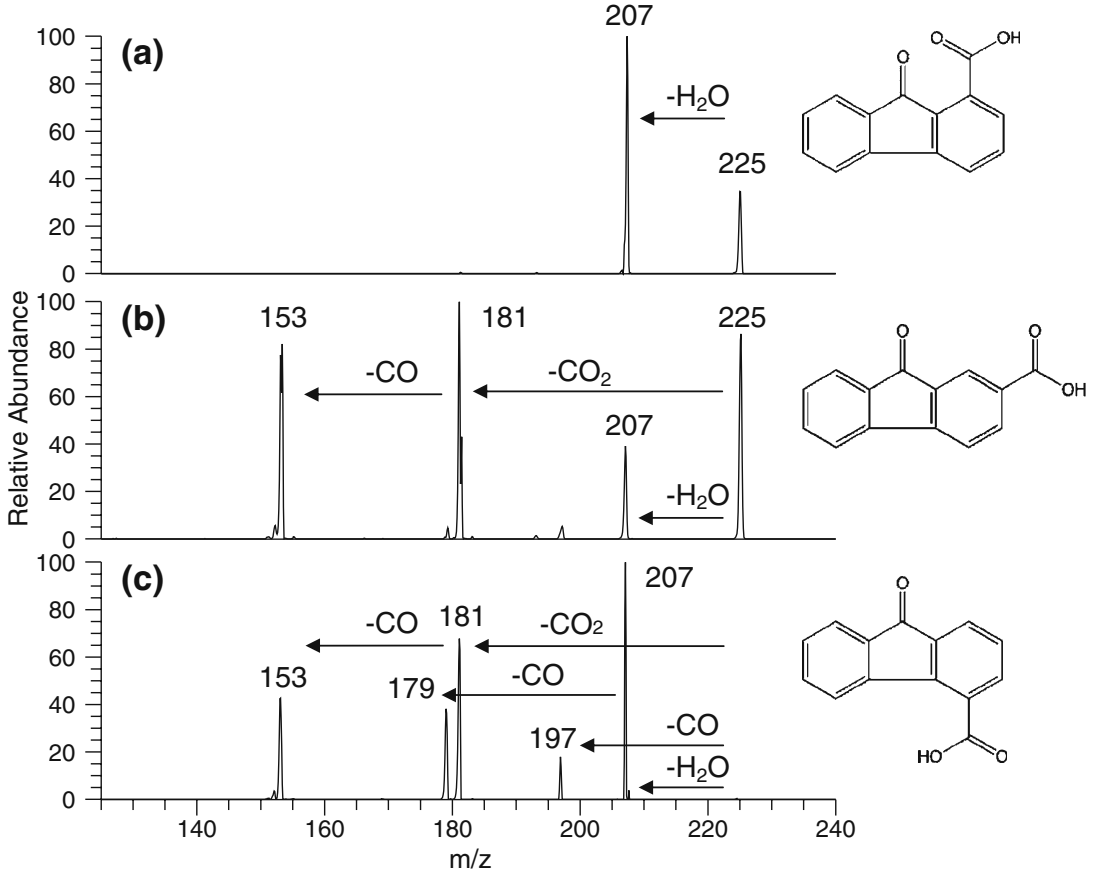

Figure 4. CAD mass spectra of isolated protonated (a) 9-fluorenone-1-carboxylic acid, (b) 9-fluorenone-2-carboxylic acid, and (c) 9-fluorenone-4-carboxylic acid

benzene (Fig. 1b and c). Possible mechanisms for this reaction are shown in Schemes 2 and 3. Isolation of the fragment ion of $\mathrm{m} / \mathrm{z} 149$ formed by the loss of benzene, followed by $\mathrm{CAD}\left(\mathrm{MS}^{3}\right)$ and then an ion-molecule reaction, provides information on the location of the carboxylic acid group in the 3 - and 4-isomers. The fragment ion of $\mathrm{m} / \mathrm{z} 149$ of both isomers fragments by loss of CO $(\mathrm{m} / \mathrm{z}$ 121) (Fig. 2), possibly to yield the phenylium ions shown in Schemes 2 and 3. Support for the formation of highly reactive phenylium ions is provided by the fact that these ions $(\mathrm{m} / \mathrm{z}$

Table 2. Summary of the main fragment ions observed in positive-mode $\mathrm{APCI} / \mathrm{MS}^{n}$ for protonated 9-fluorenone carboxylic acids

\begin{tabular}{|c|c|c|c|c|}
\hline Analyte (MW) & $\mathrm{MS}(\mathrm{m} / \mathrm{z})$ & $\begin{array}{l}\mathrm{MS}^{2} \text { CAD fragments and } \\
\text { other products }(\mathrm{m} / \mathrm{z})\end{array}$ & $\begin{array}{l}\mathrm{MS}^{3} \mathrm{CAD} \text { fragments and } \\
\text { other products }(\mathrm{m} / \mathrm{z})\end{array}$ & $\begin{array}{l}\mathrm{MS}^{4} \mathrm{CAD} \text { fragments and } \\
\text { other products }(\mathrm{m} / \mathrm{z})\end{array}$ \\
\hline $\begin{array}{l}\text { 9-Fluorenone-1-carboxylic } \\
\text { acid (224) }\end{array}$ & {$[\mathrm{M}+\mathrm{H}]^{+}(225)$} & $225-\mathrm{H}_{2} \mathrm{O}(207)[100 \%]$ & $\begin{array}{l}207-\mathrm{CO}(179)[38 \%] \\
207-\mathrm{CO}+\mathrm{H}_{2} \mathrm{O}(197)^{\mathrm{a}}[62 \%]\end{array}$ & $179-\mathrm{CO}(151)$ [100\%] \\
\hline $\begin{array}{l}\text { 9-Fluorenone-2-carboxylic } \\
\text { acid (224) }\end{array}$ & {$[\mathrm{M}+\mathrm{H}]^{+}(225)$} & $\begin{array}{l}225-\mathrm{H}_{2} \mathrm{O}(207)[16 \%] \\
225-\mathrm{CO}(197)[3 \%] \\
225-\mathrm{CO}_{2}(181)[47 \%] \\
225-\mathrm{H}_{2} \mathrm{O}-\mathrm{CO}(179)[2 \%] \\
225-\mathrm{CO}_{2}-\mathrm{CO}(153)[32 \%]\end{array}$ & $\begin{array}{l}207-\mathrm{CO}(179)[38 \%] \\
207-\mathrm{CO}+\mathrm{H}_{2} \mathrm{O}(197)^{\mathrm{a}}[62 \%] \\
181-\mathrm{CO}(153)[100 \%]\end{array}$ & $179-\mathrm{CO}(151)[100 \%]$ \\
\hline $\begin{array}{l}\text { 9-Fluorenone-4-carboxylic } \\
\text { acid (224) }\end{array}$ & {$[\mathrm{M}+\mathrm{H}]^{+}(225)$} & $\begin{array}{l}225-\mathrm{H}_{2} \mathrm{O}(207)[50 \%] \\
225-\mathrm{CO}(197)[13 \%] \\
225-\mathrm{CO}_{2}(181)[16 \%] \\
225-\mathrm{H}_{2} \mathrm{O}-\mathrm{CO}(179)[10 \%] \\
225-\mathrm{CO}_{2}-\mathrm{CO}(153)[11 \%]\end{array}$ & $\begin{array}{l}207-\mathrm{CO}(179)[16 \%] \\
207-\mathrm{CO}+\mathrm{H}_{2} \mathrm{O}(197)^{\mathrm{a}}[84 \%] \\
197-\mathrm{CO}_{2}(153)[100 \%] \\
181-\mathrm{CO}(153)[100 \%]\end{array}$ & $179-\mathrm{CO}(151)[100 \%]$ \\
\hline
\end{tabular}

aan-molecule reaction with adventitious $\mathrm{H}_{2} \mathrm{O}$. 
<smiles>O=C(O)c1cccc2c1C(=[OH+])c1ccccc1-2</smiles>

\section{$\overrightarrow{\mathrm{CAD}}$}

$\mathrm{m} / \mathrm{z} 225$<smiles>O=C1c2ccccc2-c2cccc([C+]34CO[C@@H]3C4)c21</smiles><smiles>O=C1CCCCC1</smiles>

m/z 207

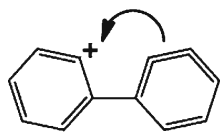<smiles></smiles><smiles>CCC</smiles><smiles>O=C([OH2+])c1cccc2c1C(=O)c1ccccc1-2</smiles><smiles></smiles><smiles>[TeH2]</smiles><smiles>CCC(=O)c1ccccc1-c1ccccc1</smiles><smiles>[O-][C+]1CC1</smiles>

m/z 179<smiles>c1ccc2c(c1)-c1ccccc1-2</smiles><smiles>[13CH3]</smiles><smiles></smiles>

$\mathrm{m} / \mathrm{z} 151$

Scheme 4. Proposed mechanisms for the consecutive losses of water and two CO molecules from protonated 9-flourenone1-carboxylic acid

121) react with adventitious $\mathrm{H}_{2} \mathrm{O}$ by addition $(\mathrm{m} / \mathrm{z} 139)$. However, the reaction rate is different for the two isomers. Hence, the $\mathrm{MS}^{3}$ spectra measured for the 3- and 4benzoylbenzoic acids show clear differences in the relative abundances of the CAD product ion of $m / z 121$ and its ionmolecule reaction product of $m / z 139$ (Fig. 3). The fragment ion of $\mathrm{m} / \mathrm{z} 121$ derived from 4-benzoylbenzoic acid undergoes the addition with $\mathrm{H}_{2} \mathrm{O}$ faster than its 3-isomer, resulting in a more abundant ion of $\mathrm{m} / \mathrm{z} 139$. The different behaviors of the fragment ions of $\mathrm{m} / \mathrm{z} 149$ derived from 3-benzoylbenzoic and 4-benzoylbenzoic acids may be rationalized by considering the charge distributions in the final water addition product. Resonance stabilization of the charge is better for the 4-isomer than the 3 -isomer since the charge is delocalized in the ortho-
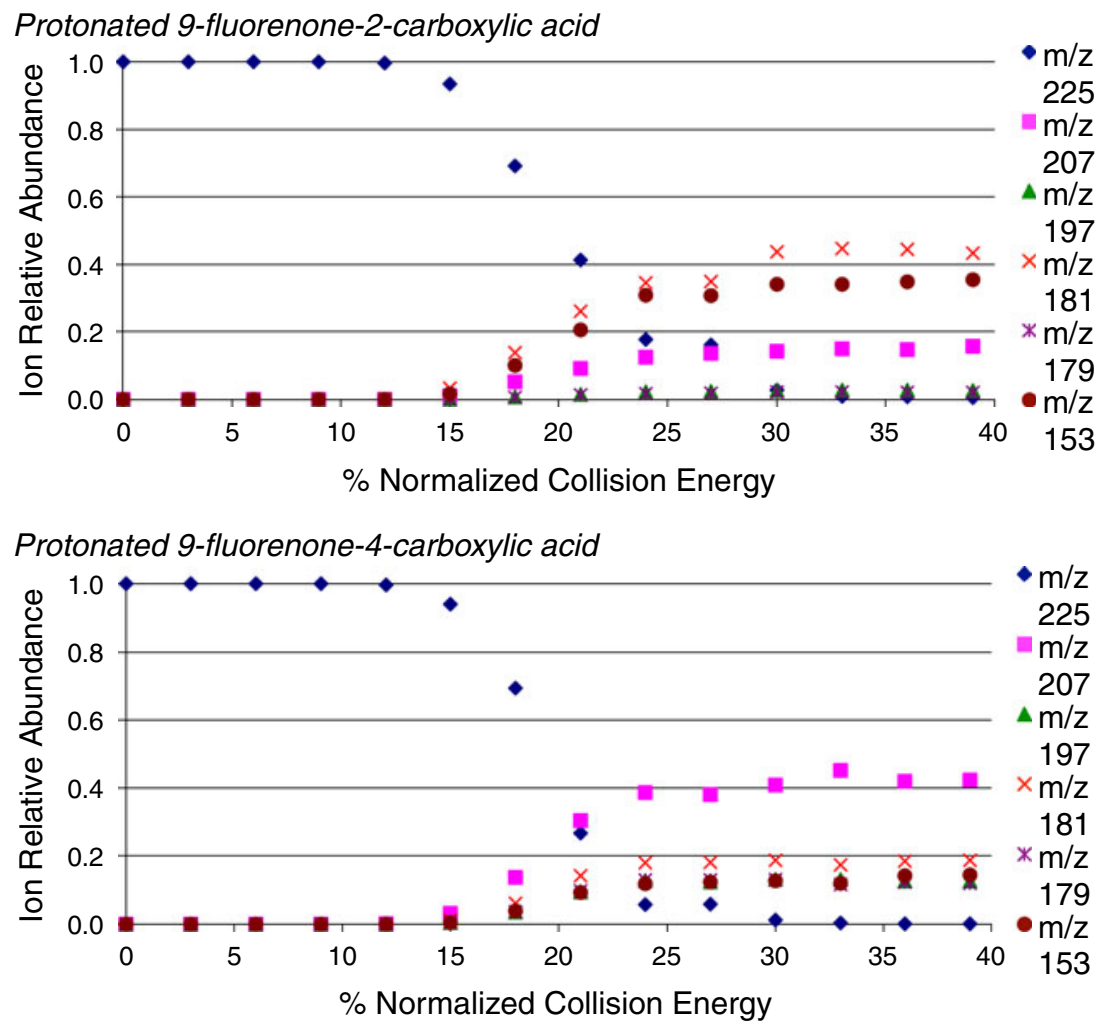

Figure 5. Energy-resolved CAD mass spectra of protonated 9-fluorenone-2-carboxylic and 9-fluorenone-4-carboxylic acids 

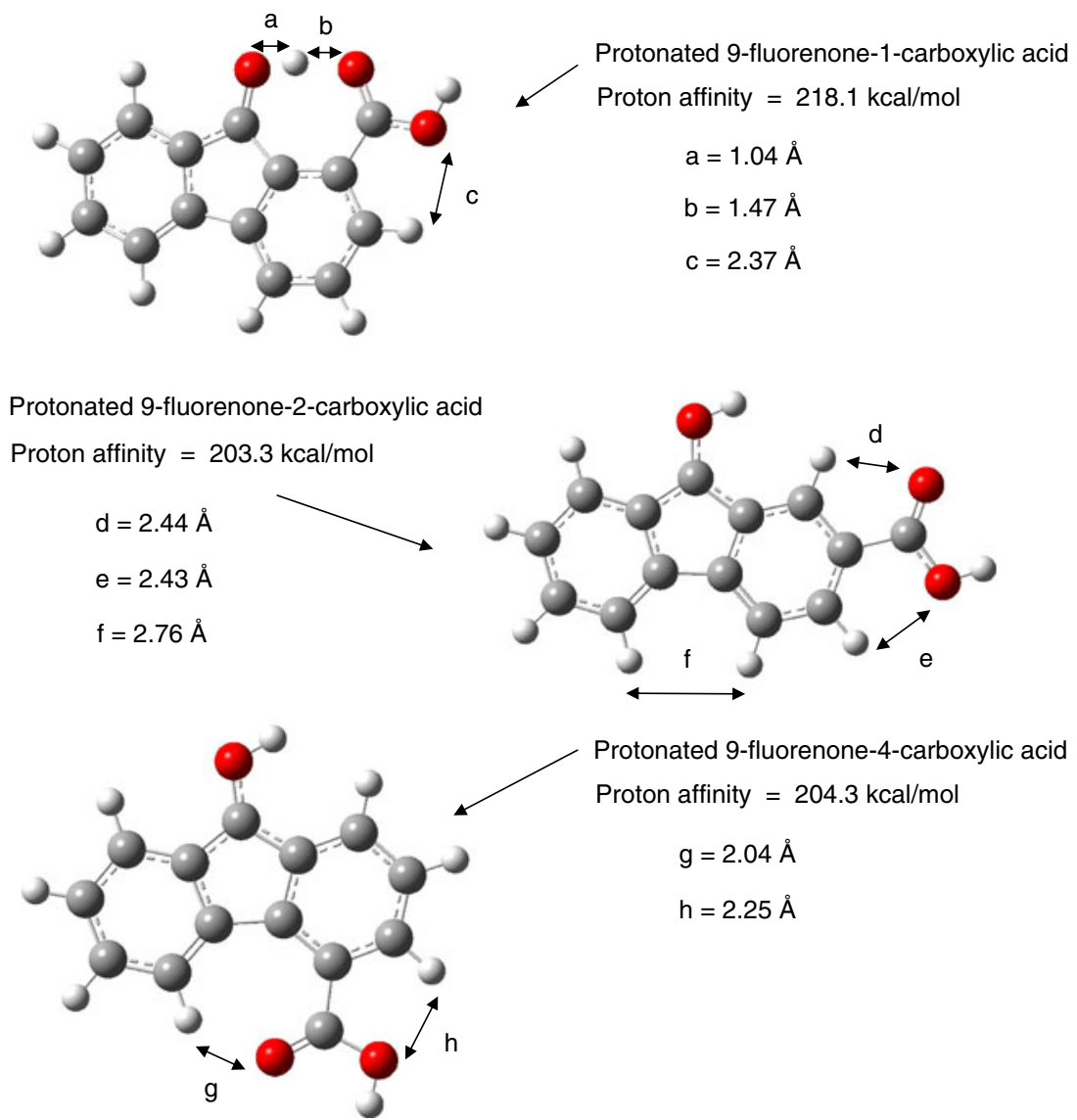

Figure 6. Optimized ground state geometries and proton affinities of the protonated monocarboxylated fluorenone isomers obtained using density functional theory at the B3LYP/6-31 G(d) level

and para-positions with respect to the electron-withdrawing carboxylic acid moiety (Schemes $\mathbf{2}$ and $\mathbf{3}$ ). Hence, the water addition should be more favorable for the 4-isomer.

Some support for the above discussion is provided by the examination of the fragmentation reactions of another fragment ion, that formed by loss of benzene and $\mathrm{CO}_{2}(\mathrm{~m} / \mathrm{z}$ 105) from the protonated 3-benzoylbenzoic and 4-benzoylbenzoic acids. Upon a second CAD event, this ion fragments by loss of $\mathrm{CO}$, thus generating another phenylium ion. Also this ion readily adds to water.

\section{9-Fluorenone Carboxylic Acid Isomers}

The CAD spectra measured for the three protonated 9fluorenone carboxylic acid isomers $(\mathrm{m} / \mathrm{z} 225)$ studied here were found to depend on the exact location of the functional groups (Fig. 4), similarly as for the benzoylbenzoic acid isomers (Table 2). When the carboxylic acid functionality is close to the keto group (9-fluorenone-1-carboxylic acid), the protonated molecule fragments by exclusive loss of $\mathrm{H}_{2} \mathrm{O}$ to produce an ion of $\mathrm{m} / \mathrm{z} 207$ (Fig. 4a), possibly via the mechanism shown in Scheme 4. The same was observed for the 2-benzoylbenzoic acid, as discussed above. This reactivity allows the distinction of the 1-fluorenone isomer from the 2- and 4-isomers.
When the carboxylic acid moiety is not close to the keto group (9-fluorenone-2-carboxylic acid and 9-fluorenone-4carboxylic acid), the protonated molecule fragments via loss of $\mathrm{H}_{2} \mathrm{O}(\mathrm{m} / \mathrm{z} 207), \mathrm{CO}(\mathrm{m} / \mathrm{z} 197), \mathrm{CO}_{2}(\mathrm{~m} / \mathrm{z} 181)$, loss of both $\mathrm{CO}$ and $\mathrm{H}_{2} \mathrm{O}\left(\mathrm{m} / \mathrm{z}\right.$ 179), or loss of both $\mathrm{CO}$ and $\mathrm{CO}_{2}(\mathrm{~m} / \mathrm{z}$ 153) (Fig. $4 \mathrm{~b}$ and c). For the 2- and 4-isomers, as opposed to the isomeric 3- and 4-benzoylbenzoic acid, benzene elimination was not observed, as this would require the cleavage of several bonds.

A comparison of the energy-resolved CAD spectra of protonated 9-fluorenone-2-carboxylic acid and 9-fluorenone4-carboxylic acid shows clear differences (Fig. 5). Protonated 9-fluorenone-2-carboxylic acid predominantly fragments by loss of $\mathrm{CO}_{2}(\mathrm{~m} / \mathrm{z} 181)$, sometimes followed by the loss of $\mathrm{CO}(\mathrm{m} / \mathrm{z} 153)$. In sharp contrast, protonated 9fluorenone-4-carboxylic acid predominantly fragments by loss of $\mathrm{H}_{2} \mathrm{O}(\mathrm{m} / \mathrm{z}$ 207) although several other abundant fragment ions were also observed.

Molecular orbital calculations were performed in order to better understand the different fragmentation patterns of the protonated 9-fluorenone carboxylic acid isomers. The optimized geometries of these protonated analytes are shown in Fig. 6. The computational studies suggest that protonation of the 9-fluorenone carboxylic acid isomers most likely 

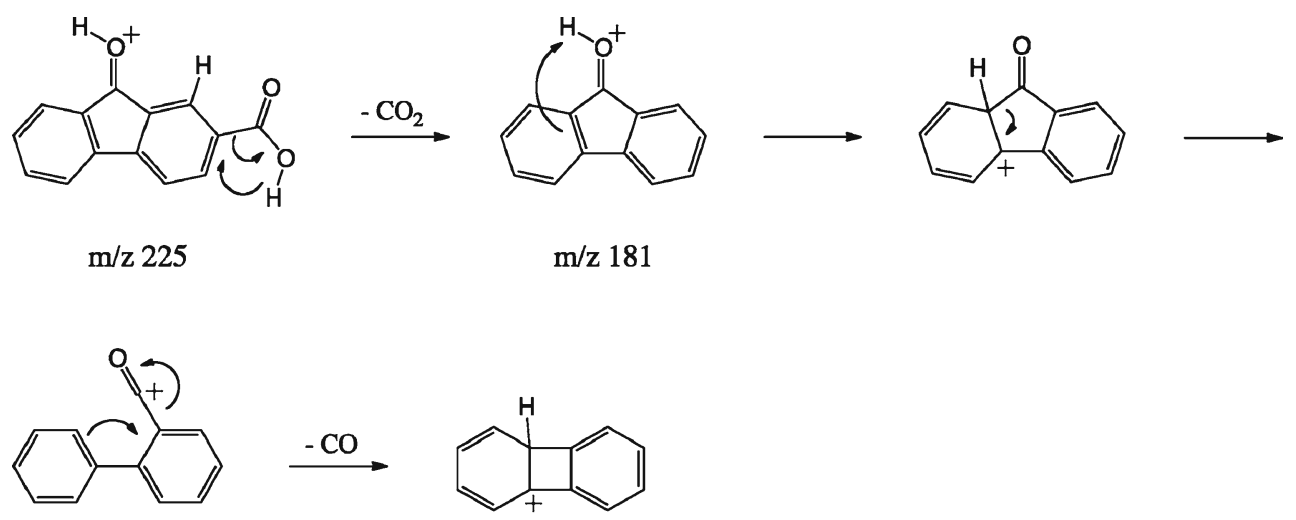

$\mathrm{m} / \mathrm{z} 153$

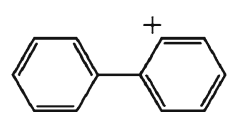

Scheme 5. Proposed mechanisms for the consecutive losses of carbon dioxide and CO from protonated 9-flourenone-2carboxylic acid. The ring-closed isomer of $\mathrm{m} / \mathrm{z} 153$ shown above was calculated to be $18.1 \mathrm{kcal} / \mathrm{mol}$ lower in energy than the ring-opened isomer shown above right

occurs on the keto group. The carbonyl groups of the carboxylic acid moieties of the 2- and 4-isomers were calculated to be 5.4 and $10.2 \mathrm{kcal} / \mathrm{mol}$ less basic than their keto groups, respectively. 9-Fluorenone-1-carboxylic acid is calculated to have a much greater proton affinity than its isomers (Fig. 6). It was also found that protonation of the 1isomer on the carbonyl group of the carboxylic acid moiety resulted in the same optimized geometry and calculated proton affinity as protonation of the keto group. This is most likely due to hydrogen bond stabilization of the proton due

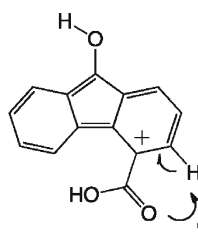

$86.3 \mathrm{kcal} / \mathrm{mol}$<smiles>OC(O)C1CCC2CC1C1C3C=CC=CC3C(O)C21</smiles>

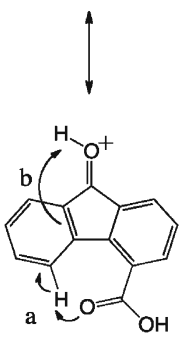

$83.6 \mathrm{kcal} / \mathrm{mol}$

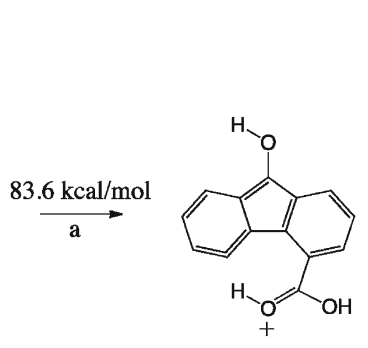

$\mathrm{m} / \mathrm{z} 225$

b $\mid 26.4 \mathrm{kcal} / \mathrm{mol}$

$\longrightarrow$

$$
\text { (1) }
$$

$\mathrm{cal} / \mathrm{mol}$
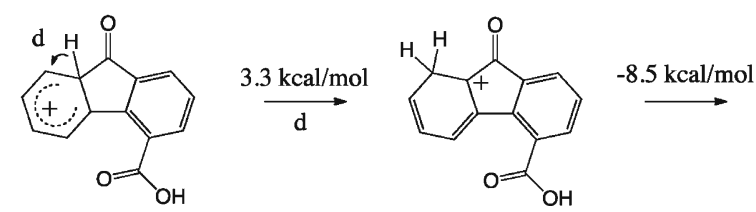

$1.8 \mathrm{kcal} / \mathrm{mol}$<smiles>O=C(O)C1C=CCC2C(=O)[C@@H]3CCCCC3C12</smiles>

$-11.9 \mathrm{kcal} / \mathrm{mol}$

Scheme 6. The proposed mechanisms for loss of water from protonated 9-flourenone-4-carboxylic acid. The indicated values represent enthalpy changes of reactions 


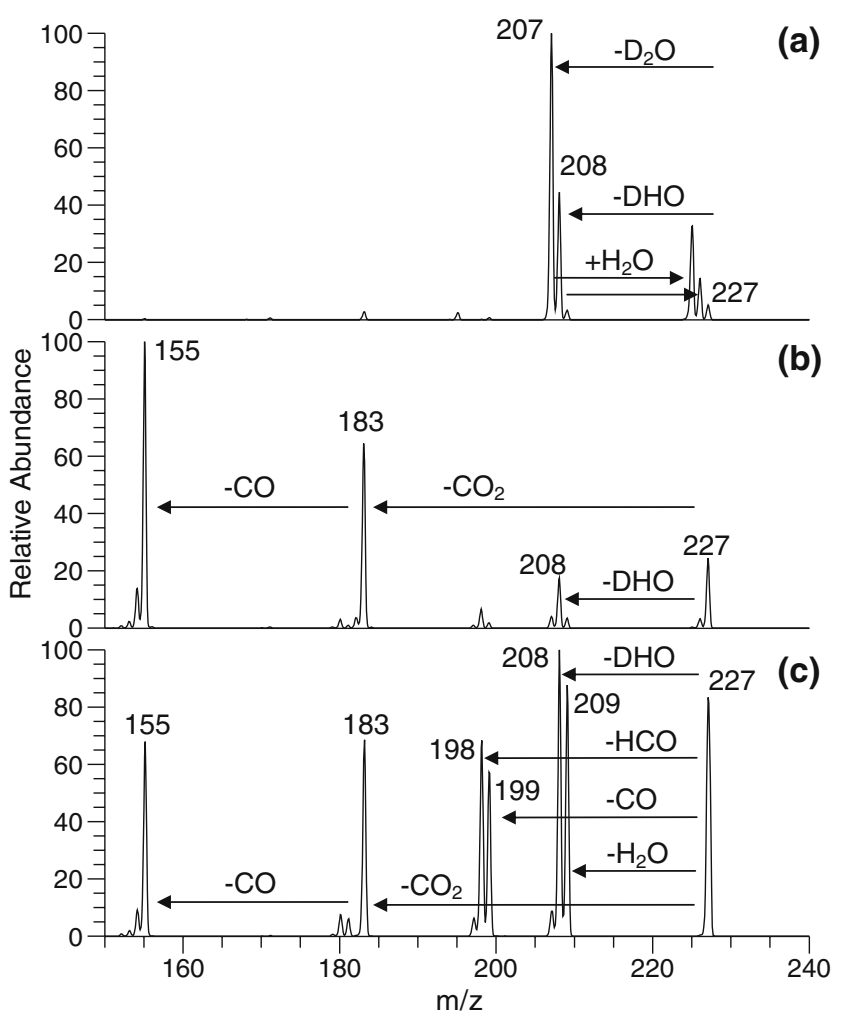

Figure 7. CAD mass spectra of isolated, doubly deuterium labeled ( $m / z 227[M+2 D-H])$ (a) 9-fluorenone-1-carboxylic acid , (b) 9-fluorenone-2-carboxylic acid, and (c) 9-fluorenone-4-carboxylic acid

to the closeness of the two basic functionalities. The same characteristic is most likely the cause of the facile loss of $\mathrm{H}_{2} \mathrm{O}$ upon CAD of the protonated 1-isomer (Scheme 4).

The calculated proton affinities (Fig. 6) of 9-fluorenone2-carboxylic acid and 9-fluorenone-4-carboxylic acid are similar. The differences between the protonated molecules fragmentation patterns are most likely due to the dissimilar distances between the carboxylic acid moiety and the closest aromatic hydrogen atoms, as shown in the mechanisms proposed for the major fragmentation pathways of each ion (Schemes 5 and 6, respectively). Loss of $\mathrm{CO}$ after the dominant loss of $\mathrm{CO}_{2}$ (Scheme 5) from protonated 9fluorenone-2-carboxylic acid is proposed to occur similarly as the loss of benzene from protonated isomeric 3- and 4benzoylbenzoic acids (Schemes $\mathbf{2}$ and $\mathbf{3}$ ). However, since the fluorenone skeleton stays together after this bond cleavage, as opposed to benzoylbenzoic acids, the reaction does not lead to immediate loss of benzene but instead to loss of $\mathrm{CO}$.

Fragmentation by loss of $\mathrm{H}_{2} \mathrm{O}$, which is the major pathway for the 4-isomer and a less important pathway for the 2-isomer, is suggested to be initiated by intramolecular proton transfer to the aromatic ring (the other pathways examined would require substantially more energy; see Scheme 6 for the 4-isomer). This is the same mechanism that was proposed above to lead to benzene loss from the protonated benzoylbenzoic acids (Schemes 2 and 3), and loss of $\mathrm{CO}$ from the 2-fluorenone isomer after loss of $\mathrm{CO}_{2}$ (Scheme 5). The proton transfer from the carbonyl group to the aromatic ring in the protonated 4-fluorenone isomer may be followed by a series of 1,2-hydride shifts around the aromatic core until an acidic proton is located very close to the carboxylic acid functionality in the adjacent ring (Scheme 6). Proton transfer to the carboxylic acid functionality then leads to rearomatization of the initially protonated benzene ring and loss of $\mathrm{H}_{2} \mathrm{O}$. The relatively short distance between the carbonyl oxygen of the carboxylic acid moiety and the aromatic hydrogen atom located on the adjacent benzene ring is likely the reason why protonated 9fluorenone-4-carboxylic acid predominantly fragments via loss of $\mathrm{H}_{2} \mathrm{O}$ (Scheme 6). The distances between the carboxylic carbonyl oxygen and the nearby aromatic hydrogen atoms for the 2-isomer are much larger.

Deuterium labeling experiments were conducted in order to further explore the proposed fragmentation mechanisms. This was performed by dissolving the analytes in completely deuterated methanol before introduction into the APCI source of the mass spectrometer. Upon ionization, three ionized molecules $\left([\mathrm{M}+\mathrm{H}]^{+}\right.$of $m / z 225,[\mathrm{M}+\mathrm{D}]^{+}$of $m / z 226$, and $[\mathrm{M}+2 \mathrm{D}-\mathrm{H}]^{+}$of $\left.m / z 227\right)$ were produced. Their relative abundances varied drastically depending on the tuning parameters of the mass spectrometer. Ionization via deuteron attachment to the keto group in the undeuterated precursor formed the deuterated ion of $\mathrm{m} / \mathrm{z} 226$. Deuteron attachment to a precursor that had undergone one H/D exchange (the carboxylic acid proton) formed the doubly deuterated analyte ion of $\mathrm{m} / \mathrm{z} 227$. The aromatic hydrogen atoms did not participate in the H/D exchange reactions.

The CAD spectra of the isolated doubly deuterated isomeric analytes of $\mathrm{m} / \mathrm{z} 227$ are shown in Fig. 7. The results are summarized in Table 3. Upon CAD, doubly deuterated 9fluorenone-1-carboxylic acid predominantly fragments via loss of $\mathrm{D}_{2} \mathrm{O}$, as expected. This finding is consistent with the mechanism shown in Scheme 1. The more interesting observation of a loss of DHO from this doubly deuterated isomer upon $\mathrm{CAD}$ indicates that $\mathrm{H} / \mathrm{D}$ exchange must occur between the carboxylic acid deuteron and a nearby aromatic hydrogen atom. How this might occur is discussed below for the 2 -isomer.

Doubly deuterated 9-fluorenone-2- and -4-carboxylic acids primarily lose $\mathrm{DHO}$ upon $\mathrm{CAD}$, although some $\mathrm{H}_{2} \mathrm{O}$ and $\mathrm{D}_{2} \mathrm{O}$ losses were also observed (Fig. 7). The observation of a major loss of HDO and a minor loss of $\mathrm{D}_{2} \mathrm{O}$ supports the mechanism shown in Scheme 6 for the protonated 4-isomer. The proposed consecutive 1,2-hydride shifts around the aromatic ring lead to positioning of a proton to an aromatic carbon near the carboxylic acid moiety, which leads to proton transfer to the carboxylic acid moiety and then elimination of $\mathrm{H}_{2} \mathrm{O}$ (Scheme 6). The mechanism for the doubly deuterated isomer is initiated by a transfer of the deuterium ion from the carbonyl oxygen to the aromatic ring. After this, there is a $50 \%$ probability for the deuteride to shift further to another position in the ring, and a $50 \%$ probability for the hydride bound to the same carbon atom to shift instead. Each subsequent 1,2-shift 
Table 3. Summary of the main fragment ions observed in positive-mode APCI/MS ${ }^{n}$ of the doubly deuterated 9-fluorenone carboxylic acid model compounds

\begin{tabular}{|c|c|c|c|}
\hline Analyte Ion (m/z) & $\mathrm{MS}(\mathrm{m} / \mathrm{z})$ & $\begin{array}{l}\mathrm{MS}^{2} \mathrm{CAD} \text { fragments and } \\
\text { other products }(\mathrm{m} / \mathrm{z})\end{array}$ & $\begin{array}{l}\mathrm{MS}^{3} \mathrm{CAD} \text { fragments and } \\
\text { other products }(\mathrm{m} / \mathrm{z})\end{array}$ \\
\hline $\begin{array}{l}\text { 9-Fluorenone-1-carboxylic } \\
\text { acid (227) }\end{array}$ & {$[M+2 D-H]^{+}(227)$} & $\begin{array}{l}227-\mathrm{DHO}(208)[18 \%] \\
227: \mathrm{H} / \mathrm{D} \text { exchange }(226)^{\mathrm{a}}[7 \%] \\
227-\mathrm{D}_{2} \mathrm{O}(207)[55 \%] \\
227: \mathrm{H} / \mathrm{D} \text { exchange of } 226(225)^{\mathrm{a}} \\
{[20 \%]}\end{array}$ & $\begin{array}{l}208-\mathrm{CO}(180)[25 \%] \\
208-\mathrm{CO}+\mathrm{H}_{2} \mathrm{O}(198)^{\mathrm{a}}[75 \%] \\
207-\mathrm{CO}(179)[27 \%] \\
207-\mathrm{CO}+\mathrm{H}_{2} \mathrm{O}(197)^{\mathrm{a}}[73 \%]\end{array}$ \\
\hline $\begin{array}{l}\text { 9-Fluorenone-2-carboxylic } \\
\text { acid (227) }\end{array}$ & {$[M+2 D-H]^{+}(227)$} & $\begin{array}{l}227-\mathrm{H}_{2} \mathrm{O}(209)[2 \%] \\
227-\mathrm{DHO}(208)[10 \%] \\
227-\mathrm{D}_{2} \mathrm{O}(207)[2 \%] \\
227-\mathrm{HCO}(198)[4 \%] \\
227-\mathrm{DCO}(197)[1 \%] \\
227-\mathrm{CO}_{2}(183)[35 \%] \\
227-\mathrm{CO}_{2}-\mathrm{CO}(155)[46 \%]\end{array}$ & $\begin{array}{l}208-\mathrm{CO}(180)[23 \%] \\
208-\mathrm{CO}+\mathrm{H}_{2} \mathrm{O}(198)^{a}[77 \%] \\
198-\mathrm{H}_{2} \mathrm{O}(180)[54 \%] \\
198-\mathrm{CO}(170)[33 \%] \\
198-\mathrm{CO}_{2}(154)[13 \%] \\
183-\mathrm{CO}(155)[100 \%]\end{array}$ \\
\hline $\begin{array}{l}\text { 9-Fluorenone-4-carboxylic } \\
\text { acid (227) }\end{array}$ & {$[M+2 D-H]^{+}(227)$} & $\begin{array}{l}227-\mathrm{H}_{2} \mathrm{O}(209)[23 \%] \\
227-\mathrm{DHO}(208)[26 \%] \\
227-\mathrm{CO}(199)[13 \%] \\
227-\mathrm{HCO}(198)[15 \%] \\
227-\mathrm{CO}_{2}(183)[12 \%] \\
227-\mathrm{CO}_{2}-\mathrm{CO}(155)[11 \%]\end{array}$ & $\begin{array}{l}209-\mathrm{CO}(181)[9 \%] \\
209-\mathrm{CO}+\mathrm{H}_{2} \mathrm{O}(199)^{\mathrm{a}}[91 \%] \\
208-\mathrm{CO}(180)[9 \%] \\
208-\mathrm{CO}+\mathrm{H}_{2} \mathrm{O}(198)^{\mathrm{a}}[91 \%] \\
199-\mathrm{CO}_{2}(155)[100 \%] \\
198-\mathrm{CO}_{2}(154)[100 \%] \\
183-\mathrm{CO}(155)[100 \%]\end{array}$ \\
\hline
\end{tabular}

${ }^{\text {a } I o n-m o l e c u l e ~ r e a c t i o n ~ w i t h ~ a d v e n t i t i o u s ~} \mathrm{H}_{2} \mathrm{O}$.

around the aromatic ring still only has a $50 \%$ probability of transferring the deuteron. Therefore, the deuterium atom gets "diluted" during this process, and it is more likely that a proton, rather than a deuteron, is eventually transferred to the carboxylic acid group and eliminated as water (Scheme 7). This process leads to predominant elimination of DHO.
Doubly deuterated 9-fluorenone-4-carboxylic acid also shows an abundant loss of $\mathrm{H}_{2} \mathrm{O}$. This finding suggests that the carboxylic acid moiety can undergo H/D exchange with both nearby aromatic carbons. The distances between the carboxylic acid moiety and those two carbons ( $\mathbf{g}$ and $\mathbf{h}$ in Fig. 6) are much smaller than analogous distances in the 1- and 2-isomers (Fig. 6). 

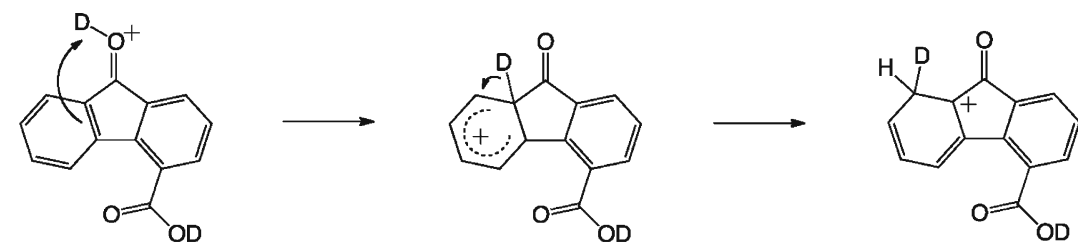

$\mathrm{m} / \mathrm{z} 227$<smiles>[2H]C1C=CC2=C(C1)C(=O)C1=CCCC(C(=O)O)=C12</smiles><smiles>[2H]C1C=CC2C(=O)c3cccc(C(=O)Oc4ccccc4)c3C2=C1</smiles><smiles>[2H]C1C=CC=C2C(=O)c3cccc(C(=O)[O-])c3C2=C1</smiles><smiles>O=C1c2cccc3c2-c2c(C[C@@H]4OCOO4)cccc2C13</smiles><smiles>[2H]c1cccc2c1-c1c(C(=O)[O-])cccc1C2=O</smiles><smiles></smiles><smiles>[2H]c1cccc2c1-c1c(C=O)cccc1C2=O</smiles>

$\mathrm{m} / \mathrm{z} 208$

Scheme 7. Proposed mechanism for the loss of DHO from the doubly deuterated 9-flourenone-4-carboxylic acid

This probably explains why the doubly deuterated 4-isomer shows a larger amount of $\mathrm{H}_{2} \mathrm{O}$ loss than either one of the other isomers.

\section{Conclusions}

The ability to use tandem mass spectrometry to elucidate the location of functional groups in unknown regioisomers would significantly increase the analytical value of this methodology. The present study demonstrates that tandem mass spectrometry experiments involving multiple ion isolation and collisionactivated dissociation and/or ion-molecule reaction steps in a LQIT mass spectrometer allows the differentiation of the model compounds studied, protonated benzoylbenzoic acid, and 9fluorenone carboxylic acid regioisomers. Further, consecutive losses of two CO groups allowed the identification and counting of the carbonyl functionalities in all analytes.

Loss of benzene allowed for the distinction of the 3- and 4benzoylbenzoic acids from the 2 -isomer, which dissociates by exclusive loss of $\mathrm{H}_{2} \mathrm{O}$. Dissimilarities in the reactivity of the phenylium ion fragment ions of 3- and 4-benzoylbenzoic acid toward $\mathrm{H}_{2} \mathrm{O}$ allowed for the unambiguous differentiation of these two isomers. It should be noted here that interfering ion/ molecule reactions with adventitious water is almost impossible to avoid in this mass spectrometer. For the 9-fluorenone carboxylic acid regioisomers, exclusive $\mathrm{H}_{2} \mathrm{O}$ loss due to hydrogen bond stabilization between the two basic groups of protonated 9-fluoreone-1-carboxylic acid allowed its differentiation from the 2- and 4-isomers. Analysis of the characteristic fragment ions in the $\mathrm{MS}^{2}$ spectra of protonated 9fluorenone-2-carboxylic acid and 9-fluorenone-4-carboxylic acid allowed for the distinction of these isomers.
Molecular orbital calculations and deuterium labeling experiments were used to explore some of the proposed fragmentation mechanisms. The examination of partially deuterium labeled ions revealed an unexpected phenomenon, "a 1,2-hydride ion tour" around an aromatic ring, until the carboxylic acid substituent is close enough to abstract a proton from an aromatic carbon and eliminate $\mathrm{H}_{2} \mathrm{O}$. This process leads to the elimination of $\mathrm{H}_{2} \mathrm{O}$ even from isomers wherein the functionalities are too far apart to interact directly. Another unexpected observation was the hydrogen/deuterium exchange between the carboxylic acid moiety and the two nearby aromatic carbons for the 4-fluorenone isomer.

The above results suggest that the differentiation of unknown regioisomers containing nearby benzoic acid or benzoic acid and keto functionalities is possible based on the employed technology. Furthermore, the carbonyl functionalities can be identified and counted based on the observed CO losses. The mechanistic findings will facilitate the interpretation of results obtained for unknown analytes. We are currently employing this technology in the analysis of lignin degradation products.

\section{Acknowledgments}

The authors gratefully acknowledge British Petroleum for partial financial support of this work. The computational research was supported as part of the Center for Direct Catalytic Conversion of Biomass to Biofuels (C3Bio), an Energy Frontier Research Center funded by the U.S. Department of Energy, Office of Science. L.M.A. acknowledges Anthony B. Costa for inspiriting discussions and help in molecular orbital calculations. 


\section{References}

1. Chang, M.C.Y.: Harnessing energy from plant biomass. Curr. Opin. Chem. Bio. 11, 677-684 (2007)

2. Ragauskas, A.J., Williams, C.K., Davison, B.H., Britovsek, G., Cairney, J., Eckert, C.A., Frederick Jr., W.J., Hallett, J.P., Leak, D.J., Liotta, C. L., Mielenz, J.R., Murphy, R., Templer, R., Tschaplinski, T.: The path forward for biofules and biomaterials. Science 311, 484-489 (2006)

3. Weng, J.-K., Li, X., Bonawitz, N.D., Chapple, C.: Emerging strategies of lignin engineering and degradation for cellulosic biofuel production. Curr. Opin. Biotech. 19, 166-172 (2008)

4. Zakzeski, J., Bruijnincx, P.C.A., Jongerius, A.L., Weckhuysen, B.M.: The catalytic valorization of lignin for the production of renewable chemicals. Chem. Rev. 110, 3552-3599 (2010)

5. Hamelinck, C.N., Hooijdonk, G., Faaij, A.P.C.: Ethanol from lignocellulosic biomass: techno-economic performance in short-, middle-, and long-term. Biomass Bioenergy 28, 384-410 (2005)

6. Li, X., Weng, J.-K., Chapple, C.: Improvement of biomass through lignin modification. Plant J. 54, 569-581 (2008)

7. Hisano, H., Nandakumar, R., Wang, Z.-Y.: Genetic modification of lignin biosynthesis for improved biofuel production. In Vitro Cell. Dev. Biol Plant. 45, 306-313 (2009)

8. Habicht, S.C., Vinueza, N.R., Archibold, E.F., Duan, P., Kenttämaa, H.I.: Identification of the carboxylic acid functionality by using electrospray ionization and ion-molecule reactions in a modified linear quadrupole ion trap mass spectrometer. Anal. Chem. 80, 3416-3421 (2008)

9. Lecchi, P., Zhao, J., Wiggins, W.S., Chen, T.-C., Yip, P.F., Mansfield, B. C., Peltier, J.M.: A method for monitoring and controlling reproducibility of intensity data in complex electrospray mass spectra: a thermometer ionbased strategy. J. Am. Soc. Mass Spectrom. 20, 398-410 (2009)

10. Ma, S., Chowdhury, S.K., Alton, K.B.: Application of mass spectrometry for metabolite identification. Curr. Drug Metab. 7, 503-523 (2006)

11. Prakash, C., Schaffer, C.L., Nedderman, A.: Analytical strategies for identifying drug metabolites. Mass Spectrom. Rev. 26, 340-369 (2007)

12. Catarina, I.V.R., Santana-Marques, M.G., Roger, F.E., Augusto, C.T., José, A.S.C., Manuel, N.: Gas-phase fragmentation of protonated C60pyrimidine derivatives. J. Mass Spectrom. 44, 911-919 (2009)

13. Kolakowski, B.M., Grossert, J.S., Ramaley, L.: The importance of both charge exchange and proton transfer in the analysis of polycyclic aromatic compounds using atmospheric pressure chemical ionization mass spectrometry. J. Am. Soc. Mass Spectrom. 15, 301-310 (2004)

14. Ramesh, M., Ramesh, V., Raju, B., Srinivas, R., Kumaraswamy, G., Markondaiah, B., Padmaja, M.: Diastereomeric differentiation of oppolzer sultam derivatives using electrospray ionization and atmospheric pressure photoionization tandem mass spectrometry. J. Mass Spectrom. 44, 1114-1118 (2009)

15. Ramesh, V., Srinivas, R., Kumaraswamy, G., Markondaiah, B.: Diastereoselectivity in the McLafferty-type rearrangement of protonated precursors of belactosin derivatives using electrospray ionization (ESI) and Atmospheric Pressure Photoionization (APPI) tandem mass spectrometry. J. Mass Spectrom. 44, 285-287 (2009)

16. Witt, M., Fuchser, J., Koch, B.P.: Fragmentation studies of fulvic acids using collision induced dissociation fourier transform ion cyclotron resonance mass spectrometry. Anal. Chem. 81, 2688-2694 (2009)

17. Yanchun, G., Shuxia, C., Donghui, W., Xiangkun, Z., Xingbo, Y., Mingsheng, T., Yufen, Z.: Fragmentation of deprotonated cyclic dipeptides by electrospray ionization mass spectrometry. J. Mass Spectrom. 44, 1188-1194 (2009)

18. Ying, L., Jiuming, H., Ruiping, Z., Jiangong, S., Zeper, A.: Study of the characteristic fragmentation behavior of hydroquinone glycosides by electrospray ionization tandem mass spectrometry with optimization of collision energy. J. Mass Spectrom. 44, 1182-1187 (2009)

19. Donovan, T., Brodbelt, J.: Selective ion molecule reactions of 2, 5dimethylpyrrole- $\gamma$-butyrolactone with dimethyl ether ions. Bio. Mass Spectrom. 21, 254-258 (1992)

20. Smith, R.J., Webb, M.I. (eds): Analysis of Drug Impurities; Blackwell Publishing: Oxford, UK, 2007

21. Palit, M., Mallard, G.: Fragmentation energy index for universalization of fragmentation energy in ion trap mass spectrometers for the analysis of chemical weapon convention related chemicals by atmospheric pressure ionization-tandem mass spectrometry analysis. Anal. Chem. 81, 2477-2485 (2009)
22. Biemann, K.: Mass spectrometry of peptides and proteins. Annu. Rev. Biochem. 61, 977-1010 (1992)

23. Badjagbo, K., Picard, P., Moore, S., Sauvé, S.: Direct atmospheric pressure chemical ionization-tandem mass spectrometry for the continuous real-time trace analysis of benzene, toluene, ethylbenzene, and xylenes in ambient air. J. Am. Soc. Mass Spectrom. 20, 829-836 (2009)

24. Auld, J., Hastie, D.R.: Tandem mass spectrometry and multiple reaction monitoring using an atmospheric pressure chemical ionization triple quadrupole mass spectrometer for product identification in atmospherically important reactions. Int. J. Mass Spectrom. 282, 9198 (2009)

25. Cao, H., Wang, Y.: Fragmentation of isomeric intrastrand crosslink lesions of DNA in an ion-trap mass spectrometer. J. Am. Soc. Mass Spectrom. 20, 611-617 (2009)

26. Vooturi, S.K., Cheung, C.M., Rybak, M.J., Firestine, S.M.: Design, synthesis, and structure-activity relationships of benzophenone-based tetra-amides as novel antibacterial agents. J. Med. Chem. 52, 50205031 (2009)

27. Negreira, N., Rodríguez, I., Ramil, M., Rubí, R.C.: Sensitive determination of salicylate and benzophenone type UV filters in water samples using solid-phase microextraction, derivatization and gas chromatography tandem mass spectrometry. Anal. Chim. Acta 638, 36-44 (2009)

28. Davies, N.W., Smith, J.A., Molesworth, P.P., Ross, J.J.: Hydrogen/ Deuterium exchange on aromatic rings during atmospheric pressure chemical ionization mass spectrometry. Rapid Comm. Mass Spectrom. 24, 1105-1110 (2010)

29. Fabrice, C., Dominique, B.-R., Saïd, Y., Catherine, M., Daniel, J., Monique, G.-A.: Online H/D exchange liquid chromatography as a support for the mass spectrometric identification of the oxidation products of melatonin. J. Mass Spectrom. 44, 318-329 (2009)

30. Fu, M., Duan, P., Li, S., Eismin, R.J., Kenttämaa, H.I.: An Ion/ Molecule reaction for the identification of analytes with two basic functional groups. 20, 1251-1262 (2009)

31. Choe, J.C., Cheong, N.R., Park, S.M.: Unimolecular dissociation of aniline molecular ion: a theoretical study. Int. J. Mass Spectrom. 279, 25-31 (2009)

32. Eduardo, A.S.E., Wilmer, E.V.N.: Density functional theory and RRKM calculations of the gas-phase unimolecular rearrangements of methylfuran and pyran ions before fragmentations. J. Mass Spectrom. 44, 1452-1458 (2009)

33. Bandu, M.L., Watkins, K.R., Bretthauer, M.L., Moore, C.A., Desaire, H.: Prediction of MS/MS Data. 1. A focus on pharmaceuticals containing carboxylic acids. Anal. Chem. 76, 1746-1753 (2004)

34. Schug, K., McNair, H.M.: Adduct formation in electrospray ionization. Part 1: common acidic pharmaceuticals. J. Sep. Sci. 25, 760-766 (2002)

35. Schug, K., McNair, H.M.: Adduct formation in electrospray ionization mass spectrometry II. Benzoic Acid Derivatives. J. Chromatogr. A 985, 531-539 (2003)

36. Lopez, L.L., Tiller, P.R., Senko, M.W., Schwartz, J.C.: Automated strategies for obtaining standardized collisionally induced dissociation spectra on a benchtop ion trap mass spectrometer. Rapid Commun. Mass Spectrom. 13, 663-668 (1999)

37. Frisch, M.J., Trucks, G.W., Schlegel, H.B., Scuseria, G.E., Robb, M. A., Cheeseman, J.R., Montgomery, J.A.J., Vreven, T., Kudin, K.N., Burant, J.C., Millam, J.M., Iyengar, S.S., Tomasi, J., Barone, B., Mennucci, B., Cossi, M., Scalmani, G., Rega, N., Petersson, G.A., Nakatsuji, H., Hada, M., Ehara, M., Toyota, K., Fukuda, R., Hasegawa, J., Ishida, M., Nakajima, T., Honda, Y., Kitao, O., Nakai, H., Klene, M., Li, X., Knox, J.E., Hratchian, H.P., Cross, J.B., Bakken, V., Adamo, C., Jaramillo, J., Gomperts, R., Stratmann, R.E., Yazyev, O., Austin, A.J., Cammi, R., Pomelli, C., Ochterski, J.W., Ayala, P.Y., Morokuma, K., Voth, G.A., Salvador, P., Dannenberg, J. J., Zarzewski, V.G., Dap-Prich, S., Daniels, A.D., Strain, M.C., Farkas, O., Malick, D.K., Rabuck, A.D., Raghayachari, K., Foresman, J.B., Ortiz, J.V., Cui, Q., Baboul, A.G., Clifford, S., Cioslowski, J., Stefanov, B.B., Liu, G., Liashenko, A., Piskorz, P., Komaromi, I., Martin, R.L., Fox, D.J., Keith, T., Al-Laham, M.A., Peng, C.Y., Nanayakkara, A., Challacombe, M., Gill, P.M.W., Johnson, B., Chen, W., Wong, M.W., Gonzalez, C., Pople, J.A.: Gaussian 03, Revision C.02 2004 Gaussian, Inc.: Wallingford, CT, (2004) 